\title{
Letting Go? The Federal Communications Commission in the Era of Deregulation
}

\author{
ROBERT W. CRANDALL *
}

The Brookings Institution

\begin{abstract}
Alfred Kahn's book, Letting Go: Deregulating the Process of Deregulation, suggested that regulators step aside once they have set basic rules for entry into erstwhile monopolized markets. Unfortunately, communications regulators have not heeded Professor Kahn's advice. I provide an analysis of the effects of three exercises in U.S. Federal Communications Commission (FCC) regulation or "deregulation": (1) the post-1996 unbundling regime designed to facilitate entry into local telecommunications markets; (2) the continuation and extension of the high-cost "universal service" program funded by the taxation of long-distance telephony; and (3) the FCC's attempt to regulate cable television rates.
\end{abstract}

\section{Introduction}

As the foremost student of the economics of regulation, Alfred E. Kahn has long recognized the merits of deregulation in markets that are arguably contestable. He ushered in the modern era of deregulation when he was Chairman of the Civil Aeronautics Board, helping to negotiate the passage of the 1978 Airline Deregulation Act. Partly as the result of that experience, he later wrote Letting Go: Deregulating the Process of Deregulation. (Kahn, 1998) Much of this volume was directed at the Federal Communications Commission (FCC) and its failure to relinquish the reins in "deregulating" telecommunications. Later, in Lessons from Deregulation: Telecommunications and Airlines after the Crunch (Kahn, 2001) amplified his 1998 thesis. In this paper, after briefly laying out Professor Kahn's cogent argument, I use three recent examples of regulatory excess in the United States in markets witnessing increasing competition and a much-reduced need for regulation.

First, I review the FCC's pursuit the regulation of new entry into local telecommunications long after it knew that its policies were futile and unnecessary. Second, I analyze the startling growth in the high-cost universal service subsidies paid to rural telephone companies without any evidence that these subsidies generate benefits in excess of their substantial costs and, indeed, that they are even necessary to create universal service in rural areas. Finally, I look back on the FCC's regulation of cable

\footnotetext{
* Senior Fellow, Economic Studies, The Brookings Institution, 1775 Massachusetts Ave., NW, Washington, DC 20036. Email: rcrandall@brookings.edu. The author is indebted to Timothy Tardiff and Dennis Weisman for valuable suggestions and to Adriane Fresh for valuable and timely research assistance.
} 
television rates in 1993-96 that was such a disaster that the Commission essentially abandoned it even before the Congress changed its mind and passed deregulatory legislation (with regard to cable television) in 1996.

Why did the Commission continue and even extend the first two policies without any evidence that they achieved their policy goals but decide to abandon cable-television rate regulation? My answer is that the first two policies were supported by major political lobbying interests while the cable-television regulations benefited no one. Even though the costs of the former two policies likely were (and may still be) far above their benefits, these costs are widely diffused and largely hidden from those who bear them. The cable television rules benefited no one, making the decision to "let go" rather easy.

\section{2 "Deregulating the process of deregulation"}

Professor Kahn's two monographs criticize regulators for micro-management of the process of deregulation. While he also discusses electric utilities in these works, his principal focus is on the FCC's management or mismanagement of telecommunications deregulation after the passage of the 1996 Telecommunications Act. Kahn asserts that the FCC and other regulatory agencies are able to micro-manage deregulation of former public utilities because the incumbents have huge sunk costs. These sunk costs can be appropriated by regulators -"kleptocrats" in the Kahn lexicon - to promote two related goals. The first is the maintenance of subsidized rates for politically favored groups after entrants drive down the over-priced rates that have historically been used to offset the losses realized on the subsidized rates. ${ }^{2}$ The second goal is the protection of new entrants. By allowing entrants to access the incumbent's facilities at low, regulated rates, the regulators can increase the probability of competitors' survival. If the entrants begin to struggle, these rates can even be reduced. Were the regulators willing to allow the subsidized rates to increase to cost-based levels, much of Kahn's concern about "kleptocracy" would be ameliorated although even such rate rebalancing would not necessarily mean that regulators would step back and allow entrants to falter.

In the modern era of telecommunications, the need for regulatory intervention has all but disappeared. Earlier concerns about "universal service” seem quaint in a country in which there are 255 million unregulated cellular subscribers among 304 million people. ${ }^{3}$ Why should the FCC and state regulators be concerned about rural fixed-wire telephone rates when aggressive competition by national wireless carriers results in national calling plans that have among the lowest per-minute rates in the world? Similarly, it seems odd that the FCC should have persevered in its attempt to protect local fixed-wire entrants from failing in 1996-2003 given the rapid growth of wireless and the sharp decline in wireless rates. Nevertheless, as Professor Kahn documents - and I discuss in considerable detail in Section 3 below - the FCC pursued a policy of progressively allowing greater access of entrants to fixed-wire incumbents' networks at low, regulated rates even as subscribers increasingly substituted wireless, cellular services for fixed-wire services.

The situation in cable television was somewhat different in 1993, when the FCC was attempting to establish a new regulatory regime in response to the 1992 Cable Television

\footnotetext{
${ }^{2}$ I use the word "subsidy" as a general description of the regulators' desire to keep certain rates artificially low. I do not attempt to determine whether these are truly subsidized prices in theory. (See Faulhaber, 1975).

${ }^{3}$ CTIA, Wireless Quick Facts available at http://www.ctia.org/advocacy/research/index.cfm/AID/10323.
} 
Consumer Protection and Competition Act (“1992 Cable Act”). ${ }^{4}$ An earlier statute, the 1984 Cable Act, had essentially deregulated cable television, in response to evidence that municipal governments has used their control over local cable franchises to block competitive entry and share in the resulting rents of monopoly franchises. When cable rates, service quality, and subscriptions rose in 1986-90, the Congress passed the 1992 Cable Act in a misguided attempt to re-impose rate regulation on cable by providing the FCC, rather than local municipalities, with new authority to establish the regulatory framework. Competition was already on the way with the first high-powered satellite about to begin service. Nevertheless, the FCC engaged in an ill-advised attempt to impose detailed rate regulation of even new channels of cable service in 1993-94, a venture that aligns nicely into Professor Kahn's description of kleptocrats micro-managing regulation with new competitive services just over the horizon.

\section{Regulating competitive entry into telecommunications, 1996-2005}

The FCC began the process of deregulating telecommunications in the late 1960s, but it was unable to deal with the problem of providing fixed-wire interconnection between the entrants and the incumbent, AT\&T. As a result, AT\&T found itself a defendant in a major antitrust suit filed by the U.S. government in 1974 which was ended with a 1982 consent decree that broke up AT\&T. ${ }^{5}$ After 12 contentious years, the task of enforcing the 1982 decree became so onerous that the Congress passed the 1996 Telecommunications Act, ${ }^{6}$ vacating the decree and establishing a new framework for regulating competitive entry.

\subsection{The 1996 Telecommunications $\mathrm{Act}^{7}$}

The 1996 Act requires incumbent local exchange carriers (ILECs) - largely, those companies divested by AT\&T under the 1982 consent decree - to "unbundle" their network facilities, that is, lease as separate facilities to entrants at regulated wholesale rates, without which prospective local entry would be "impaired". In addition, proprietary elements that are "necessary" for entry to occur would also have to be unbundled. The interpretation of the terms "necessary" and "impair" occupied the FCC and the courts for more than eight years despite the obvious failure of the entrants using the unbundled elements long before these eight years expired.

In August 1996, the FCC released its initial unbundling rules, specifying a large number of ILEC network elements that must be unbundled. ${ }^{8}$ This decision was based on the FCC's judgment that an entrant would be “impaired" by having to provide many of its own network elements because they might be of lower quality or might cost more than the regulated wholesale cost of the incumbent's facilities. This interpretation of the Act was rejected by the Supreme Court in 1999 because it was based on a conclusion that any increase in cost due to self-provisioning would impair entry. ${ }^{9}$

\footnotetext{
${ }^{4}$ Public Law 102-385 - October 5, 1992.

${ }^{5}$ Modification of Final Judgment, U.S. v. American Telephone and Telegraph Co., 552 F. Supp. 131 (D.D.C. 1982), aff'd. sub. Nom., Maryland v. United States, 460 U.S. 1001 (1983).

6 The Telecommunications Act of 1996, Pub. L. 104-104, Stat. 56, codified at 47 U.S.C. § 151 et seq.

${ }^{7}$ Much of the discussion in this section is based on Crandall (2005) and Crandall and Waverman (2006).

${ }^{8}$ U.S. FCC (1996).

${ }^{9}$ AT\&T Corp. v. Iowa Utilities Board, 525 U.S. 366 (1999).
} 
In 1999, the FCC issued new rules that required the unbundling of any network element by an ILEC if the lack of access to that element materially diminishes an entrant's ability to provide service. ${ }^{10}$ This led it to conclude that even switching should be unbundled, thereby requiring the ILECs to unbundle the entire local platform, dubbed the “UNE-P”. As a result of this decision, the new entrants' use of the ILECs' facilities began to accelerate rapidly. ${ }^{11}$ (See Figure 1) However, this new policy criterion was rejected by the U.S. Court of Appeals in 2002 as unnecessarily broad because it would require unbundling of any element that could be provided by an entrant at even small cost penalties and it failed to consider the effect on investment and innovation. ${ }^{12}$ Because such cost penalties often confront entrants into any industry and do not derive from the wasteful duplication of truly essential facilities - namely, those which cannot be duplicated economically - this criterion was seen by the Court as inconsistent with the meaning of Section 251 of the 1996 Act.

Entry advanced rapidly as the result of the FCC's liberal unbundling policies, as Figure 1 shows, but the extension of unbundling to the entire UNE-Platform was seized upon by the two largest long distance carriers, AT\&T and WorldCom (MCI); it did little to provide profitable opportunities for the new CLECs. Even though the number of CLEC lines, including those controlled by AT\&T and WorldCom, trebled from the end of 1999 to the end of 2002, the FCC had to know that its policy was failing as it drafted its new unbundling rules in 2002-03. By 2002, the financial markets had devastated the new entrants (the Competitive Local Exchange Carriers or "CLECs") because most of these companies had failed to demonstrate that they had any prospect for success. They offered no innovative new services, relying on an arbitrage margin between the ILECs' local retail price and the wholesale UNE-P rate to generate sufficient cash flows to cover their marketing expenses and their operating costs. When their financial reports showed that this generally was impossible because of the very large costs of marketing a service that was no different from the incumbent's, the market capitalization of the CLECs declined from \$91 billion at the end of 1999 to \$5.5 billion at the end of 2001 .

Many of these companies filed for bankruptcy protection by the end of 2002 and most either exited the industry or were acquired at distressed prices by other carriers. (See Table 1.) A few of the companies listed in Table 1 continue to operate, but none of them has been able to do so profitably. Cogent, ITC Delta Com, Covad, XO Communications, and Time Warner Telecommunications are still operating but generally at substantial losses. Of these companies, only Time Warner Telecommunications has a market capitalization of more than $\$ 1$ billion. Most of the companies in Table 1 were acquired at prices that were a small fraction of their cumulative capital investment and an even smaller fraction of these capital

\footnotetext{
${ }^{10}$ U.S. FCC (1999).

${ }^{11}$ In most countries, unbundling is confined to local loop unbundling, requiring the incumbent telephone company to provide access to the last-mile copper line connecting the subscriber to the company's switching facilities. Entrants are required to provide their own switching in these situations. The 1999 decision by the FCC to require every network element to be "unbundled" essentially allowed the entrant to re-sell the incumbent's service at very deep wholesale discounts without making any network investments of its own. For this reason, the “UNE-Platform” became the dominant source of the entrants' growth after 1999, accounting for approximately 16 million of the 24.6 million additional lines enrolled to the entrants from December 1999 through December 2004. (U.S. FCC, Local Competition Reports, semi-annual issues.)

${ }^{12}$ United States Telecom Association v. FCC, 290 F.3d 415 (D.C. Cir. 2002). In this decision, the DC Circuit Court of Appeals also vacated the FCC's line-sharing rules for broadband services.
} 
expenditures plus accumulated losses. This outcome was well established by 2002 as the FCC pondered its regulatory options to meet the objections of the U.S. Court of Appeals.

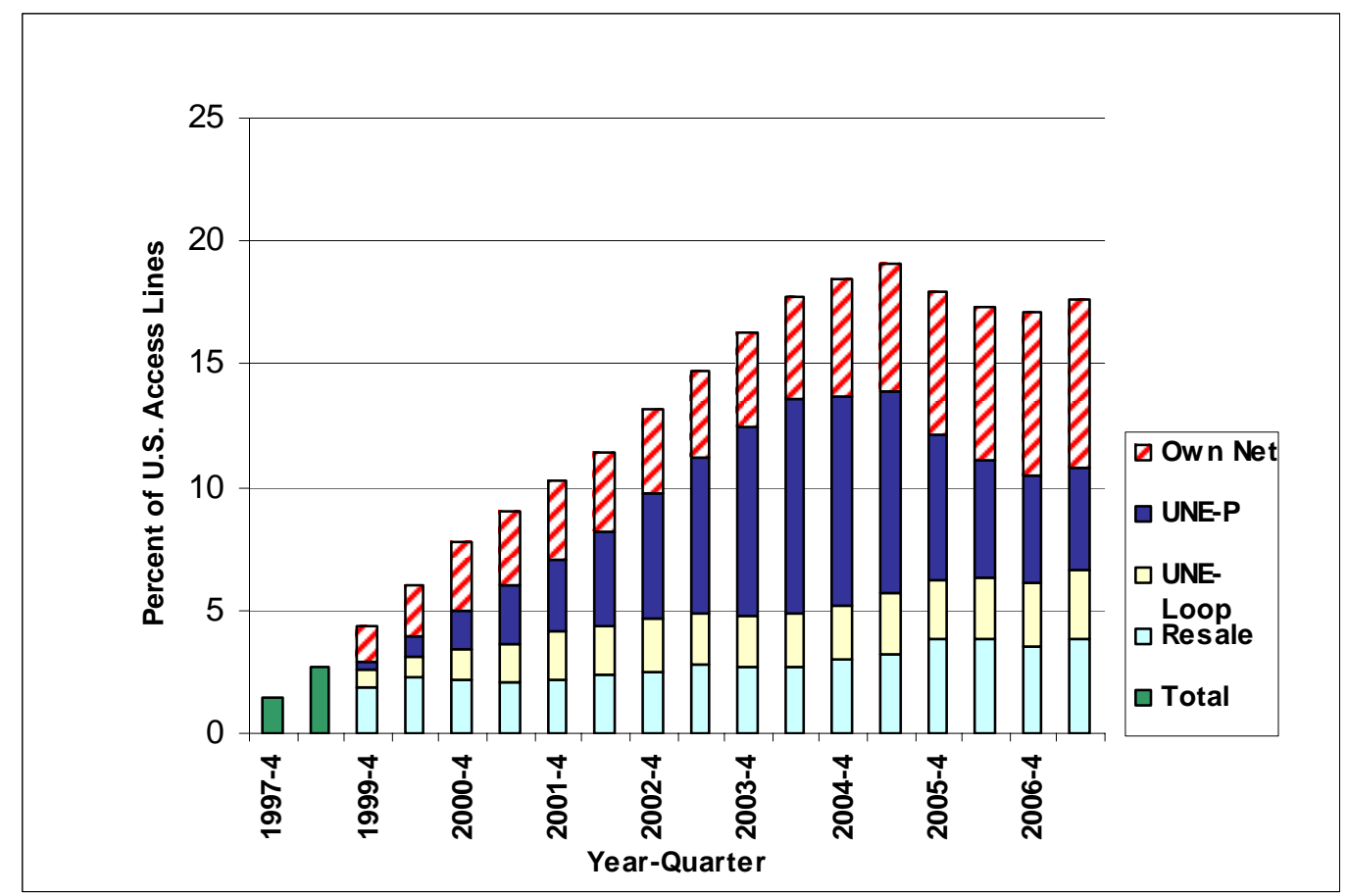

Figure 1: U.S. local competitors’ share of access lines, 1997-2007

Source: FCC, Local Telephone Competition: Status as of June 30, 2007

The FCC's unbundling policy had been designed to provide a "stepping stone" for entrants who would subsequently build out their own networks, but the FCC's own data showed that the non-cable-television company entrants had actually reduced the number of lines on their own networks from 4.1 million at the end of 2000 to 3.4 million at the end of 2002. ${ }^{13}$ Moreover, there was no evidence that the entrants were providing new services or other benefits to consumers. In short, the policy had already failed by December 2002.

Undeterred by this evidence and two court reversals, the FCC enunciated a continuation of its liberal unbundling policy in a decision announced in February 2003 but not released until August 2003 due to the FCC's reluctance to reveal its controversial contents. ${ }^{14}$ This policy would have required the continuation of "unbundling" of virtually all network elements, including switching, but it provided an opening to state public utility commissions to issue their own determinations of the need to include network switching in the list of unbundled elements. Once again, the Court of Appeals invalidated these rules, this time in an unusually harsh rebuke to the Commission for its lack of fidelity to the Court's earlier rulings. ${ }^{15}$ As a result, the admonished FCC was forced to retreat from its liberal unbundling policy in 2004, bringing an end to the availability of the UNE-P.

\footnotetext{
${ }^{13}$ Federal Communications Commission, The Status of Local Competition, semi-annual reports.

${ }^{14}$ Review of the Section 251 Unbundling Obligations of Incumbent Local Exchange Carriers, CC Dockets 01-338, et al, 2003.

${ }^{15}$ United States Telecom Association, et.al. v. FCC \& USA (D.C. Cir. 2004).
} 
However, the Commission allowed entrants to continue to have access to the UNE-P during a one-year phase-out of the old rules. Thus, perhaps the most liberal unbundling regime in the world continued into $2005,{ }^{16}$ long after it had been shown to be a dismal failure.

\begin{tabular}{|c|c|c|c|c|}
\hline Company & Evolution & $\begin{array}{l}\text { Principal entry } \\
\text { strategy }\end{array}$ & $\begin{array}{l}\text { Sale price or market } \\
\text { value } 12 / 31 / 06\end{array}$ & $\begin{array}{l}\text { Capital expenditures } \\
\text { since } 1996 \\
\text { (million) } \\
\end{array}$ \\
\hline $\begin{array}{ll}\text { Adelphia } & \text { Business } \\
\text { Solutions } & \end{array}$ & $\begin{array}{l}\text { Chapter } 11, \\
\text { March } 2002\end{array}$ & Resale/Own Net & $\begin{array}{l}\text { Acquired 5/06 for } \\
\$ 1,240 \text { million }\end{array}$ & $\$ 2,315$ \\
\hline Allegiance Telecom & $\begin{array}{l}\text { Chapter 11, May } \\
2003\end{array}$ & UNE & $\begin{array}{l}\text { Acquired 6/04 for } \$ 322 \\
\text { million }\end{array}$ & $\$ 1,372$ \\
\hline Advanced Radio & $\begin{array}{l}\text { Chapter } 11, \\
\text { March 2001 }\end{array}$ & Unknown & Closed & $\$ 76$ \\
\hline U.S. LEC & Acquired & UNE & $\begin{array}{l}\text { Acquired 8/06 for } \$ 450 \\
\text { million }\end{array}$ & $\$ 402$ \\
\hline Choice One & $\begin{array}{l}\text { Chapter 11, } \\
\text { October } 2004\end{array}$ & UNE & Taken private 11/04 & $\$ 323$ \\
\hline Cogent & Operating & UNE/Own Net & $\$ 895$ million & $\$ 272$ \\
\hline Concentric Network & Acquired & UNE & $\begin{array}{l}\text { Acquired 6/00 for } \\
\$ 3,600 \text { million }\end{array}$ & $\$ 70$ \\
\hline CoreComm & $\begin{array}{l}\text { Chapter 11, } \\
\text { January } 2004\end{array}$ & Resale, UNE-P & Taken private in 2004 & $\$ 114$ \\
\hline $\begin{array}{l}\text { Convergent } \\
\text { Communications }\end{array}$ & $\begin{array}{l}\text { Chapter } 11, \\
\text { April } 2001\end{array}$ & Resale & Closed & $\$ 83$ \\
\hline Covad Communications & $\begin{array}{l}\text { Chapter 11, } \\
\text { August } 2001\end{array}$ & UNE & $\begin{array}{l}\text { Acquired for } \$ 304 \\
\text { million in } 2007\end{array}$ & $\$ 800$ \\
\hline CTC Communications & $\begin{array}{l}\text { Chapter } 11 \text {, } \\
\text { October } 2002\end{array}$ & Resale & $\begin{array}{l}\text { Combined with Choice } \\
\text { One, taken private in } \\
2004\end{array}$ & $\$ 588$ \\
\hline CapRock & Acquired & Resale & $\begin{array}{l}\text { Acquired in } 12 / 00 \text { by } \\
\text { McLeod which entered } \\
\text { Ch. } 11 \text { in } 2005\end{array}$ & $\$ 604$ \\
\hline Cypress & Acquired & UNE & $\begin{array}{l}\text { Acquired in 2002; } \\
\text { acquirer sold for } \$ 12 \\
\text { million in } 2005\end{array}$ & $\$ 161$ \\
\hline DSLNet & Acquired & UNE & Acquired in 10/06 & $\$ 101$ \\
\hline Elec Communications & Operating & UNE-P & $\begin{array}{l}\text { Sold CLEC operations, } \\
6 / 07\end{array}$ & $\$ 3$ \\
\hline Electric Lightwave & Acquired & UNE & $\begin{array}{l}\text { Acquired in } 5 / 02 \text { for } \$ 3 \\
\text { million }\end{array}$ & $\$ 704$ \\
\hline eSpire & $\begin{array}{ll}\text { Chapter } & 11, \\
\text { March 2001 }\end{array}$ & UNE & $\begin{array}{l}\text { Sold assets for } \$ 68 \\
\text { million, } 5 / 02\end{array}$ & $\$ 921$ \\
\hline Focal Communications & $\begin{array}{l}\text { Chapter } \quad 11 \text {, } \\
\text { December } 2002\end{array}$ & UNE & $\begin{array}{l}\text { Acquired for } \$ 210 \\
\text { million in 9/04 }\end{array}$ & $\$ 674$ \\
\hline GST Telecommunications & $\begin{array}{l}\text { Chapter } 11, \\
\text { May } 2000\end{array}$ & UNE/Own Net & $\begin{array}{l}\text { Assets sold for } \$ 689 \\
\text { million in } 1 / 01\end{array}$ & $\$ 912$ \\
\hline
\end{tabular}

\footnotetext{
${ }^{16}$ I describe this as the most liberal unbundling policy in the world because no other country has mandated the "unbundling" of the entire incumbent platform. However, by 2003 the FCC had been forced to retreat from line sharing by the U.S. Court of Appeals. Most other countries now require line sharing so that entrants can offer standalone broadband services without building their own loops. In the United States, an entrant would have to lease the entire loop to do so.
} 


\begin{tabular}{|c|c|c|c|c|}
\hline ICG Telecommunications & $\begin{array}{l}\text { Chapter 11, } \\
\text { November } 2000\end{array}$ & UNE/Own Net & $\begin{array}{l}\text { Assets sold for } \$ 6 \\
\text { million in } 7 / 04\end{array}$ & $\$ 2,725$ \\
\hline Intermedia Communications & Acquired & UNE & $\begin{array}{l}\text { Acquired in } 10 / 00 \text {; } \\
\text { acquirer filed for Ch. } 11 \\
\text { in } 7 / 02 \text {. }\end{array}$ & $\$ 2,085$ \\
\hline ITC DeltaCom & $\begin{array}{l}\text { Chapter 11, } \\
\text { June } 2002\end{array}$ & UNE & \$387 million & $\$ 1,036$ \\
\hline McLeodUSA & $\begin{array}{lr}\text { Chapter } & 11, \\
\text { January } & 2002 \\
\text { and } & \text { October } \\
2005 & \end{array}$ & UNE/ Resale & Taken private in $1 / 06$ & $\$ 3,910$ \\
\hline MPower & $\begin{array}{ll}\text { Chapter } & 11, \\
\text { April } 2002 & \\
\end{array}$ & UNE & $\begin{array}{l}\text { Acquired for } \$ 204 \\
\text { million in 8/04 }\end{array}$ & $\$ 654$ \\
\hline Network Access Solutions & $\begin{array}{l}\text { Chapter 11, } \\
\text { June } 2002\end{array}$ & UNE & Assets sold in $1 / 03$ & $\$ 87$ \\
\hline Network Plus & $\begin{array}{l}\text { Chapter 11, } \\
\text { February } 2002\end{array}$ & UNE & $\begin{array}{l}\text { Acquired for } \$ 16 \text { million } \\
3 / 02\end{array}$ & $\$ 367$ \\
\hline Northpoint Communications & $\begin{array}{ll}\text { Chapter } & 11, \\
\text { March 2001 }\end{array}$ & UNE & $\begin{array}{l}\text { Assets sold for } \$ 135 \\
\text { million in } 2001\end{array}$ & $\$ 517$ \\
\hline Net 2000 & $\begin{array}{ll}\text { Chapter } 11, \\
\text { November } 2001\end{array}$ & UNE/ Resale & $\begin{array}{l}\text { Assets acquired for } \$ 25 \\
\text { million in } 1 / 02\end{array}$ & $\$ 204$ \\
\hline $\begin{array}{ll}\text { Nextlink } & \text { (XO } \\
\text { Communications) }\end{array}$ & $\begin{array}{l}\text { Chapter 11, } \\
\text { June } 2002\end{array}$ & UNE/ Own Net & $\$ 1,078$ million & $\$ 4,628$ \\
\hline Pointe Communications & Acquired & UNE & $\begin{array}{l}\text { Acquired by private } \\
\text { company in } 7 / 99 \text {. }\end{array}$ & $\$ 25$ \\
\hline RCN & $\begin{array}{l}\text { Chapter 11, } \\
\text { May } 2004\end{array}$ & Own Net/Resale & $\$ 1,004$ million & $\$ 3,252$ \\
\hline Rhythms Net Connections & $\begin{array}{l}\text { Chapter 11, } \\
\text { August } 2001\end{array}$ & UNE & $\begin{array}{l}\text { Assets sold for } \$ 28 \\
\text { million in } 12 / 01\end{array}$ & $\$ 374$ \\
\hline Talk America & Acquired & UNE-P & $\begin{array}{lrr}\text { Acquired for } & \$ 251 \\
\text { million in } 12 / 06 & \\
\end{array}$ & $\$ 98$ \\
\hline Teligent & $\begin{array}{l}\text { Chapter 11, } \\
\text { May } 2001\end{array}$ & Own Net & $\begin{array}{l}\text { Acquired for } \$ 99 \text { million } \\
\text { in } 1 / 05\end{array}$ & $\$ 739$ \\
\hline Telocity & Acquired & UNE & $\begin{array}{l}\text { Acquired for } \$ \$ 180 \\
\text { million in } 12 / 00\end{array}$ & $\$ 46$ \\
\hline $\begin{array}{l}\text { Time Warner } \\
\text { Telecommunications }\end{array}$ & Operating & Own Net & $\$ 3,290$ & $\$ 2,096$ \\
\hline Winstar & $\begin{array}{l}\text { Chapter 11, } \\
\text { May } 2001\end{array}$ & Own Net/ UNE & $\begin{array}{l}\text { Acquired for } \$ 43 \text { million } \\
\text { in } 12 / 01\end{array}$ & $\$ 2,596$ \\
\hline ZTel (Trinsic) & $\begin{array}{l}\text { Chapter 11, } \\
\text { February 2007 }\end{array}$ & UNE-P & \$5 million & $\$ 123$ \\
\hline
\end{tabular}

Table 1: The failure of U.S. CLECs, 1996-present.

Source: Author's tabulations from company financial reports

\subsection{The cost of the FCC's unbundling regime}

Between 1997 and 2006, the new CLECs shown in Table 1 reported capital expenditures of $\$ 38$ billion. I estimate that these companies accounted for about one-half of all CLEC 
lines, excluding those supplied by cable television companies. ${ }^{17}$ At the end of 2006, total non-cable CLEC lines totalled 21.9 million, according to FCC data; the public CLECs therefore accounted for a maximum of about 11 million subscriber lines. The marketing expenses to attract these 11 million subscribers may be estimated at another $\$ 3.5$ billion to $\$ 4$ billion, assuming marketing costs of $\$ 350$ to $\$ 400$ per subscriber. Thus, the public CLECs in Table 1 invested at least $\$ 41.5$ billion to achieve a subscriber level of about 11 million lines.

Even if the CLECs were able to retain these subscribers indefinitely and assuming that the invested capital lasted forever, the annual capital charges per subscriber at a 12 percent cost of capital would be $\$ 450$ per subscriber per year. Furthermore, under the most generous assumption that the CLECs' operating costs were no greater than the ILECs' avoided retail costs, the unbundling regime would have to have generated at least $\$ 450$ per subscriber per year in new value to the CLECs' subscribers for the benefits of this policy to exceed its costs. This would be nearly two times the average residential rate reported by the ILECs between 1996 and 2006 and approximately equal to the average single-line ILEC business rate over the period. Given that the CLEC lines were split approximately 60:40 between business and residential subscribers, the net gain to a subscriber from shifting from an ILEC to a CLEC would have to be substantially greater than the total price paid for the service prior to the shift for this policy to have created net benefits.

The new entrants offered very little additional value to residential subscribers. This is the reason that the CLECs incurred such large marketing costs to induce residential subscribers to shift from the established carriers. The only thorough econometric study of the value of the entrants' services, conducted solely with New York data, suggested that the average residential consumer realized \$2.77 per month in benefits from switching to AT\&T and $\$ 1.13$ from switching to MCI from the incumbent (Verizon) service. ${ }^{18}$ Most of this total could not be attributed to consumer cost savings and was therefore assigned to a "quality" improvement which simply involved billing the Verizon service, offered over the UNE Platform, as an AT\&T or MCI service. But even the $\$ 2.77$ estimate pales in comparison to the additional social cost of nearly $\$ 40$ per month.

Presumably, there have been some benefits to business subscribers who shifted from the incumbents' services to the new competitors, but we have no estimates of these benefits. The average monthly rates charged by the incumbents for single-line business service has actually risen somewhat since 1996, suggesting that they have not been forced to reduce rates to the smaller business customers in order to fend off the CLEC competition. On the other hand, the "special access" rates paid by the large enterprise customers that use CLEC facilities, such as those supplied by Level 3, declined due to the new competition, but these competitive services do not rely nearly as much on the FCC's unbundling regime as do the services to residences and small businesses. Indeed, the FCC has chosen to forbear from the regulation of the higher-speed services in many urban areas because of the availability of competitive alternatives to the incumbents' lines. ${ }^{19}$

\footnotetext{
${ }^{17}$ A substantial share of the CLEC lines were accounted for by AT\&T and WorldCom (MCI) because of the FCC's decision to require the wholesale offering of the UNE-P at low, regulated rates. There are also a substantial number of lines supplied by private CLECs who do not appear in Table 1.

${ }^{18}$ Economides, Sim, and Viard (2008).

${ }^{19}$ A lively controversy has erupted over the FCC's decision to grant pricing flexibility to these high-capacity services in many metropolitan areas. See GAO, FCC Needs to Improve Its Ability to Monitor and Determine the Extent of Competition in Dedicated Access Services, November 29, 2006, suggesting that competition in these markets may not be very robust. See also William Taylor, Supplemental Declaration, filed in FCC, In
} 
It thus seems highly unlikely that the FCC's wholesale unbundling regime could have generated economic benefits that are more than a small fraction of the cost of the capital lured into local telecom markets by this regime since 1996 and subsequently abandoned or disposed of at fire-sale prices. If one were to add to these costs the additional operating costs of the entrants, the enormous legal expenses involved in the regulatory and legal process required to maintain this regime, and the likely depressing effect on ILEC investment, the excess of costs over benefits would be magnified substantially. The FCC had sufficient evidence by 2002 to allow it to pull back from this regulatory adventure, yet it chose to continue the battle with the DC Circuit, prolonging the excesses of unbundling into 2005 and 2006.

\subsection{Why did the FCC persevere?}

The only reason for continuing this unfortunate strategy was to keep the struggling CLECs alive a little longer. Two very large companies, AT\&T and MCI, lobbied strenuously for a continuation of the unbundling policy, and the FCC accommodated them despite the lack of any evidence that they or the other CLECs were using unbundled lines or the UNE-P as stepping stones towards full facilities-based competition with the ILECs. ${ }^{20}$ In early 2003, when the FCC was deciding how to respond to yet another court setback, the new CLEC entrants had already collapsed. There was very little left of these entrants that could be propped up even temporarily by any further extension on the FCC's unbundling policy.

AT\&T and MCI offered slightly more hope. Both were struggling to survive because their long-distance operations were being crushed by the competition from low-cost wireless services. Wireless was becoming a major source of competition for local fixed access also. And the cable companies were also entering the fray, preparing to offer telephony through new Voice over Internet Protocol (VoIP) technology. In this highly competitive environment, WorldCom was being reorganized in bankruptcy. When it emerged from bankruptcy in 2004, its market cap was approximately equal to the sum of all of the surviving CLEC entrants. AT\&T was still in existence even though it had failed badly in trying to operate two of the country's largest cable systems and had spun off its wireless operations. Its market cap had fallen by about 75 percent in the two and one-half years prior to the FCC's release of its 2003 unbundling decision.

Neither AT\&T nor MCI could have survived simply as long distance carriers, but neither one had any hope of building its own local fixed-wire or wireless network. In this environment, the FCC's decision to cling to its unbundling rules can only be understood as a political act to keep these two struggling giants alive a little longer at the cost of reducing the ILECs' market value a little more. Another dose of kleptocracy provided a short-term life support system even though the UNE-P could not possibly rescue these two failing companies from ultimate collapse. ${ }^{21}$

the Matter of Special Access Rates for Price Cap Local Exchange Carriers, WC Docket No. 05-25 and WC Docket No. 05-25, August 8, 2007, showing that special access rates have fallen substantially since 1996.

${ }^{20}$ As I related on p.485 above, the CLECs were not moving from UNE loops or UNE-P's to building their own mass-market subscriber connections. There is a substantial literature on the effects of the unbundling regime on network investment by CLECs and ILECs that the FCC summarizes at S179 of the August 2003 Triennial Review Order. The FCC viewed this literature as "inconclusive”, but no one has shown that any of the CLECs had moved from unbundled loops, shared loops, or the UNE-P's to building its own loops at any time during this long period of futile promotion of “competition” by the FCC.

${ }^{21}$ Ultimately, one can only speculate why the FCC would have risked another rebuke by the U.S. Court of Appeals by extending this futile UNE-P policy given that the policy could not bail out MCI and AT\&T from 
When the DC Circuit overturned the FCC's rules yet again in 2004, this struggle ended, requiring AT\&T and MCI to surrender to the ILECs in 2005. The long-distance business was in a state of terminal decline. Cable and wireless telephony were surging. The vertical fragmentation of the U.S. telecommunications sector came to an abrupt end when Verizon bought MCI and SBC bought AT\&T, thereby ending the FCC's attempt to create a competitive local fixed-wire market through mandatory unbundling. ${ }^{22}$ Local competition developed despite (not because of) the FCC's attempt to subsidize it. This competition continues to intensify as traditional ILECs, wireless carriers, and cable television companies battle for voice, data, and video customers in a battle that does not depend on mandated network unbundling.

\section{$4 \quad$ High-cost universal service policy}

The federal "high-cost" universal service policy for basic telephone service is appropriately named; the policy has extremely high social costs which simply keep climbing. The objective of the high-cost universal-service policy is to provide rural telephone companies with subsidies to offset their high costs so that they may price their basic telephone services at levels that allow even the most dispersed households to choose to subscribe. The goal, achieved decades ago, is universal service.

Providing such subsidies might be a worthwhile social objective if (1) raising the subsidy monies does not result in a large loss in social output, (2) the policy reduces rural rates, and (3) the lower rates are necessary to induce universal service. Unfortunately, there is little published evidence that any of these three requirements is satisfied by the current policy. Before turning to each of these requirements, however, we need a few details.

\subsection{The growth of the program}

Subsidies for rural services in the U.S. are hardly new or limited to telephony. Electrical service, postal service, highways, and even air transport services have been subject to rural subsidies for decades. Rural telephone subsidies began with low-interest loans to rural telephone co-operatives, and then they spread through the design of the regulated rate structure. Long distance rates were held artificially high during the period in which AT\&T enjoyed a virtual monopoly over long distance service and local service in areas with about 85 percent of the U.S. population. A large share of the revenues collected from long distance service was diverted to local carriers, including AT\&T's own local exchange operations, through a largely invisible "separations and settlements” process. In earlier

their continuing decline as stand-alone long distance carriers. For some reason, a majority of FCC commissioners voted for this policy and then battled internally for six months trying to work out language that would justify it.

${ }^{22}$ This is not to say that the independent, non-cable CLECs have disappeared, but they are continuing to decline. Between June 2005 and June 2007, the latest date for which the FCC has published the data, the number of CLEC lines declined by 5.2 million while the number of cable-television provided lines increased by 3.2 million. Thus, the number of non-cable CLEC lines declined by 8.4 million, which is equal to the decline in the number of UNE lines that the ILECs reported over these two years. As Tardiff and Weisman (2008) point out, some of this decline is due to the reclassification of the heretofore (old) AT\&T and MCI lines from CLEC lines to ILEC lines. 
research, Leonard Waverman and I estimated that this "reverse Ramsey pricing" of telephone service created economic welfare losses of as much as $\$ 7$ billion per year. ${ }^{23}$

\begin{tabular}{|c|c|c|c|c|c|c|c|c|c|}
\hline Year & $\begin{array}{c}(1) \\
\text { High- } \\
\text { Cost } \\
\text { Loop } \\
\text { Support }\end{array}$ & $\begin{array}{c}\text { (2) } \\
\text { Safety } \\
\text { Net } \\
\text { Additive } \\
\text { Support }\end{array}$ & $\begin{array}{c}\text { (3) } \\
\text { Safety } \\
\text { Valve } \\
\text { Support } \\
\end{array}$ & $\begin{array}{c}\text { (4) } \\
\text { High- } \\
\text { Cost } \\
\text { Model } \\
\text { Support }\end{array}$ & $\begin{array}{c}\text { (5) } \\
\text { Long- } \\
\text { Term } \\
\text { Support }\end{array}$ & $\begin{array}{c}(6) \\
\text { Interstate } \\
\text { Common } \\
\text { Line } \\
\text { Support } \\
\end{array}$ & $\begin{array}{c}\text { (7) } \\
\text { Interstate } \\
\text { Access } \\
\text { Support }\end{array}$ & $\begin{array}{c}\text { (8) } \\
\text { Local } \\
\text { Switching } \\
\text { Support }\end{array}$ & $\begin{array}{c}\text { Total } \\
\text { Support }\end{array}$ \\
\hline 1986 & $\$ 56$ & - & - & - & - & - & - & - & $\$ 56$ \\
\hline 1987 & 126 & - & - & - & - & - & - & - & 126 \\
\hline 1988 & 183 & - & - & - & - & - & - & - & 183 \\
\hline 1989 & 265 & - & - & - & $\$ 236$ & - & - & - & 500 \\
\hline 1990 & 339 & - & - & - & 263 & - & - & - & 602 \\
\hline 1991 & 485 & - & - & - & 272 & - & - & - & 757 \\
\hline 1992 & 609 & - & - & - & 306 & - & - & - & 915 \\
\hline 1993 & 705 & - & - & - & 323 & - & - & - & 1,028 \\
\hline 1994 & 725 & - & - & - & 347 & - & - & - & 1,072 \\
\hline 1995 & 750 & - & - & - & 382 & - & - & - & 1,132 \\
\hline 1996 & 763 & - & - & - & 426 & - & - & - & 1,188 \\
\hline 1997 & 794 & - & - & - & 470 & - & - & - & 1,263 \\
\hline 1998 & 827 & - & - & - & 473 & - & - & $\$ 390$ & 1,690 \\
\hline 1999 & 864 & - & - & - & 473 & - & - & 380 & 1,718 \\
\hline 2000 & 874 & - & - & $\$ 219$ & 478 & - & $\$ 279$ & 385 & 2,235 \\
\hline 2001 & 927 & - & - & 206 & 492 & - & 577 & 390 & 2,592 \\
\hline 2002 & 1,045 & - & - & 233 & 493 & $\$ 173$ & 615 & 376 & 2,935 \\
\hline 2003 & 1,085 & $\$ 9$ & $\$ 0$ & 234 & 504 & 415 & 622 & 396 & 3,265 \\
\hline 2004 & 1,137 & 12 & 0 & 273 & 275 & 716 & 642 & 414 & 3,468 \\
\hline 2005 & 1,219 & 15 & 4 & 292 & 0 & 1,149 & 691 & 426 & 3,796 \\
\hline 2006 & 1,309 & 29 & 1 & 358 & 4 & 1,266 & 681 & 448 & 4,096 \\
\hline 2007 & 1,402 & 38 & 3 & 346 & - & 1,392 & 645 & 460 & 4,287 \\
\hline
\end{tabular}

Table 2: High-cost support fund payments (millions of dollars)

Source: FCC, derived from NECA and USAC data

When AT\&T was broken up in 1984, its long-distance operations were severed from its local telephone operations, thereby requiring any payments from the long-distance company to local carriers to be made explicitly through interstate and intrastate access charges. The FCC regulated interstate access charges and managed the transition from long distance monopoly to long distance competition by establishing an equal-access regime as mandated by the consent decree that settled the antitrust case. Shifting from implicit to

${ }^{23}$ Crandall and Waverman (2000). 
explicit access fees in this fashion, however, exposed the fact that long distance access charges were far above the actual cost of originating and terminating telephone calls, resulting in a huge loss of economic welfare from the suppression of relatively price-elastic long distance service. The FCC immediately began to reduce these interstate access charges, substituting a monthly "subscriber line charge" for them - essentially, increasing local rates.

The shift away from implicit subsidies of local companies through over-pricing long distance service did not leave rural telephone companies unscathed. To offset the loss in implicit subsidies for these rural companies, the FCC and the states designed a new "highcost" universal service subsidy program that was to be paid for in large part by an FCCimposed surcharge (that is, tax) on interstate and international telephone revenues. This high-cost fund was phased in gradually as Table 2 shows, but by 1993 the total amount of subsidy paid to rural carriers in various forms of high-cost support had risen to over $\$ 1$ billion. The fund began to grow again in 1998-99 as the FCC shepherded agreements among carriers to reduce interstate access charges even farther. ${ }^{24}$ The extension of the high-cost subsidies to new, competitive carriers in rural areas further increased the total payments, which have now surpassed $\$ 4$ billion per year.

Further rural subsidies continue to exist in the form of higher long-distance access charges for rural companies than for urban and suburban companies. But the federal highcost universal service program itself must be funded through a tax on interstate and international long distance services because the FCC cannot tax intrastate services. Thus, the cost of the new federal high-cost fund as well as new "universal service" programs designed to subsidize telecom services for schools, libraries, and rural health facilities are still supported by interstate and international long distance voice/data revenues. The welfare-reducing effect of taxing higher-price-elasticity voice/data usage to subsidize lower-price-elasticity fixed access remains. ${ }^{25}$

The high-cost payments summarized in Table 2 reflect a very complicated set of programs administered by the Universal Service Administrative Company (USAC). The details of each of the programs reflected in Table 2 cannot be explained fully in this paper, but the reader should understand that the payments shown in columns (1) through (4) are designed to support intrastate services, that is, local rates, while the payments in columns (5) through (8) are designed to hold down interstate carrier and subscriber line access charges. ${ }^{26}$ Most of the support is designed to offset the "non-traffic-sensitive" costs of telephone service - those costs that do not vary with the number of calls made by end users. Only the "Local Switching Support" is aimed at defraying traffic-sensitive costs, that is, costs that vary with the number of minutes of network use.

These high-cost subsidies are just one part of the FCC's universal service program which must be funded by fees levied on interstate and international revenues. The program also provides more than $\$ 800$ million in low-income support, which is paid to local carriers to offset revenue losses from discounts offered to low-income subscribers. ${ }^{27}$ And a new program, launched by the 1996 Telecommunications Act, provides about $\$ 1.8$ billion per

\footnotetext{
${ }^{24}$ There were two separate efforts in this regard, the CALLS program for the larger "price-cap” carriers, and the MAG plan for smaller, rate-of-return regulated carriers.

${ }^{25}$ The FCC has eliminated high-speed DSL revenues from the revenue base.

${ }^{26}$ The interested reader can find a full description in the annual Federal-State Joint Board Universal Service Monitoring Reports available on the FCC's website at http://www.fcc.gov/wcb/iatd/monitor.html.

${ }^{27}$ These data are available in the annual Universal Service Monitoring Reports.
} 
year to fund advanced telecommunications service subsidies for schools, libraries, and rural health facilities. These additional programs result in an annual federal universalservice funding requirement of about $\$ 7$ billion.

\begin{tabular}{|l|l|}
\hline First quarter: & Rate (\%) \\
\hline 1998 & 3.9 \\
\hline 1999 & 3.8 \\
\hline 2000 & 5.9 \\
\hline 2001 & 6.7 \\
\hline 2002 & 6.8 \\
\hline 2003 & 7.3 \\
\hline 2004 & 8.7 \\
\hline 2005 & 10.7 \\
\hline 2006 & 10.2 \\
\hline 2007 & 9.7 \\
\hline
\end{tabular}

Table 3: Universal service contribution factors 1998-2007

Source: FCC, Trends in Telephone Service, February 2007, Table 19.17

The growth of the universal-service program has taken place against a backdrop of declining revenues for traditional fixed-line telephone service. The number of local lines in service has declined from 189.4 million at the end of 1999 to just 163.2 million at the end of June 2007..$^{28}$ Between 2000 and 2006, fixed-wire local service revenues declined from $\$ 84.5$ billion to $\$ 78.2$ billion, and long distance revenues - intrastate and interstate/international - declined from $\$ 87.8$ billion to just $\$ 49.3$ billion. ${ }^{29}$ But interstate and international revenues have declined even more rapidly, from $\$ 49.3$ billion to $\$ 24.6$ billion. ${ }^{30}$ The overwhelming share of the latter decline is due to a shift from fixed-wire long distance calling to wireless (cellular) services, but the result has been stagnation in traditional voice revenues. Thus, a tax on interstate/international long-distance revenues to support a declining local-service business and new mandates for subsidizing advanced services in schools, libraries, and rural health facilities requires a rapidly-rising tax, as Table 3 shows.

High-cost subsidies have grown very unevenly across the various states as Table 4 demonstrates. It may seem surprising that the payments to Alabama, Mississippi, and Hawaii have grown so rapidly while payments to New York and New Hampshire have actually declined. Similarly, payments to Colorado, Idaho, and Montana - western states that have large rural areas - have grown very little while payments to the farm states of the Dakotas, Minnesota, Iowa, and Kansas have grown rapidly. These differences cannot be explained by the differences in the growth of population and, therefore, telephone lines in these states. Much of the difference is explained by various idiosyncrasies in the high-cost program.

First, the high-cost program includes payments to the large Bell companies in some states, recently based on a "forward-looking" model of costs. These payments are shown in

\footnotetext{
${ }^{28}$ FCC, Status of Local Competition as of June 30, 2007, Table 1.

${ }^{29}$ FCC, Telephone Industry Revenue Report: 2005, June 2007, Table 1.

${ }^{30}$ Id., Table 9.
} 
column (4) of Table 2. Surprisingly, the large, incumbent local carriers in Alabama, Kentucky, and Mississippi collect about 75 percent of these high-cost "model support" monies.

Second, new competitive carriers, including cellular carriers, are now eligible for these high-cost subsidies. In 2006, these newer carriers received almost \$1 billion of the $\$ 4.1$ billion in high-cost subsidies.

Finally, the variance in the reported non-traffic sensitive (NTS) costs of the small rural carriers is very large. Part of this is due to the variance in the underlying economics of serving dispersed subscribers in areas of different topography. But a substantial share of the variance is also due to the fact that the high-cost rural subsidy program is based on historical costs. If a rural carrier has NTS costs that are less than 15 percent above an indexed national average, it receives no high-cost loop support. However, if its costs are 15 to 50 percent above the national average, it receives 65 percent of its costs in excess of 115 percent of the national average. If its costs are more than 150 percent of the national average, it receives 75 percent of its costs above 150 percent of the national average. Such a mechanism obviously diminishes the incentive to invest in cost-reducing technologies.

\begin{tabular}{|c|c|c|c|}
\hline State or Jurisdiction & 2000 payments & 2006 payments & Percent change \\
\hline ALABAMA & $88,214,302$ & $115,970,829$ & $190.60 \%$ \\
\hline ALASKA & $70,315,653$ & $153,585,925$ & $149.60 \%$ \\
\hline ARIZONA & $35,577,804$ & $83,015,183$ & $133.33 \%$ \\
\hline ARKANSAS & $71,691,402$ & $132,506,172$ & $84.83 \%$ \\
\hline CALIFORNIA & $64,070,553$ & $106,057,527$ & $65.53 \%$ \\
\hline COLORADO & $53,761,542$ & $79,538,461$ & $47.95 \%$ \\
\hline CONNECTICUT & 952,617 & $2,148,111$ & $125.50 \%$ \\
\hline DELAWARE & 199,512 & 260,862 & $30.75 \%$ \\
\hline FLORIDA & $49,781,316$ & $81,606,733$ & $63.93 \%$ \\
\hline GEORGIA & $79,228,268$ & $107,717,393$ & $35.96 \%$ \\
\hline HAWAII & $2,403,015$ & $40,796,515$ & $1597.72 \%$ \\
\hline IDAHO & $35,787,777$ & $52,129,985$ & $45.66 \%$ \\
\hline ILLINOIS & $31,342,473$ & $67,769,463$ & $116.22 \%$ \\
\hline INDIANA & $30,488,022$ & $63,456,867$ & $108.14 \%$ \\
\hline IOWA & $30,643,488$ & $105,624,742$ & $244.69 \%$ \\
\hline KANSAS & $67,053,729$ & $190,190,329$ & $183.64 \%$ \\
\hline KENTUCKY & $29,807,009$ & $99,107,332$ & $232.50 \%$ \\
\hline LOUISIANA & $72,467,664$ & $126,982,778$ & $75.23 \%$ \\
\hline MAINE & $32,099,073$ & $36,950,556$ & $15.11 \%$ \\
\hline MARYLAND & $2,580,717$ & $4,547,043$ & $76.19 \%$ \\
\hline MASSACHUSETTS & $1,285,080$ & $2,826,798$ & $119.97 \%$ \\
\hline MICHIGAN & $39,393,036$ & $58,938,320$ & $49.62 \%$ \\
\hline MINNESOTA & $48,130,605$ & $119,894,357$ & $149.10 \%$ \\
\hline MISSISSIPPI & $132,785,751$ & $276,033,154$ & $107.88 \%$ \\
\hline MISSOURI & $65,568,381$ & $86,089,210$ & $31.30 \%$ \\
\hline MONTANA & $45,254,916$ & $78,159,025$ & $72.71 \%$ \\
\hline NEBRASKA & $23,729,919$ & $81,771,480$ & $244.59 \%$ \\
\hline NEVADA & $15,066,537$ & $31,253,755$ & $107.44 \%$ \\
\hline NEW HAMPSHIRE & $8,489,304$ & $8,076,985$ & $-4.86 \%$ \\
\hline NEW JERSEY & $3,688,155$ & $1,278,738$ & $-65.33 \%$ \\
\hline NEW MEXICO & $37,100,202$ & $65,528,235$ & $76.63 \%$ \\
\hline NEW YORK & $51,532,557$ & $48,922,256$ & $-5.07 \%$ \\
\hline NORTH CAROLINA & $33,997,699$ & $81,469,482$ & $139.63 \%$ \\
\hline NORTH DAKOTA & $25,437,877$ & $80,902,743$ & $218.04 \%$ \\
\hline $\mathrm{OHIO}$ & $19,503,900$ & $41,582,298$ & $113.20 \%$ \\
\hline OKLAHOMA & $67,401,390$ & $123,629,485$ & $83.42 \%$ \\
\hline
\end{tabular}




\begin{tabular}{|l|l|l|l|}
\hline OREGON & $47,354,850$ & $72,249,837$ & $52.57 \%$ \\
\hline PENNSYLVANIA & $28,472,919$ & $65,514,151$ & $130.09 \%$ \\
\hline PUERTO RICO & $141,441,540$ & $123,321,116$ & $14.71 \%$ \\
\hline RHODE ISLAND & 25,686 & 34,734 & $35.23 \%$ \\
\hline SOUTH CAROLINA & $46,068,145$ & $81,894,819$ & $77.77 \%$ \\
\hline SOUTH DAKOTA & $22,225,041$ & $89,471,093$ & $302.57 \%$ \\
\hline TENNESSEE & $34,482,177$ & $51,813,674$ & $50.26 \%$ \\
\hline TEXAS & $138,101,139$ & $230,723,265$ & $67.07 \%$ \\
\hline UTAH & $12,535,251$ & $24,173,848$ & $92.85 \%$ \\
\hline VERMONT & $26,244,471$ & $30,837,973$ & $17.50 \%$ \\
\hline VIRGINIA & $38,477,018$ & $79,510,400$ & $106.64 \%$ \\
\hline WASHINGTON & $53,885,595$ & $102,762,965$ & $90.71 \%$ \\
\hline WEST VIRGINIA & $63,450,822$ & $70,341,070$ & $10.86 \%$ \\
\hline WISCONSIN & $54,591,597$ & $134,208,754$ & $145.84 \%$ \\
\hline WYOMING & $29,896,680$ & $57,637,426$ & $92.79 \%$ \\
\hline TOTAL & $2,234,771,101$ & $4,096,321,267$ & $83.30 \%$ \\
\hline
\end{tabular}

Table 4: High-cost universal service payments by state (\$)

Source: FCC, Universal Service Monitoring Reports

\subsection{Rural residential rates versus urban rates}

To illustrate the effect of the high-cost program on telephone rates, I have chosen to compare urban and rural rates in the state of Iowa, a state with many subsidized rural carriers, one largely unsubsidized rural carrier (Iowa Telecom) ${ }^{31}$ and no particularly difficult topographical problems. Iowa does not resemble Alaska or western Montana; its high costs would seem to derive almost entirely from the population density of an agricultural state.

The average reported NTS cost per line for rural carriers in Iowa was $\$ 353$ in 2005, the most recent year for which complete data are available, and the variance was \$134. Moreover, the rate of increase in these costs varies tremendously - even for carriers whose line counts have not changed perceptibly.

In this section, I look at the rates paid by rural and urban subscribers in Iowa for subsidized telephone service and a comparable, unsubsidized service, cable television. Fixed-wire telephone service has many of the cost characteristics of modern cable television services. Both have distribution plant costs that decline with population density. A cable television system does not have to invest in a circuit switch, but most systems now offer high-speed Internet service, requiring substantial investment at their head-ends. Citing SNL Kagan statistics, the National Cable Telecommunications Association (NCTA) claims that cable television now passes more than 123 million U.S. households. Thus, cable television is virtually ubiquitous despite not being able to collect high-cost subsidies from the federal or state governments. Does the lack of subsidies show up in higher rural cable rates?

\footnotetext{
${ }^{31}$ Iowa Telecom, which was formed through the acquisition of the rural Iowa operations of GTE, a large incumbent carrier that was acquired by Bell Atlantic, the forerunner of Verizon, does not receive any traditional high-cost universal service subsidies because its embedded costs per loop are below the threshold required for support. It does, however, receive “Interstate Access Support”, a program that was created in 2000 as part of a program to shift a portion of implicit subsidies removed from price cap carriers’ interstate access to an explicit recovery mechanism.
} 
In Table 5, I show the range of telephone and cable television rates in a sample of rural communities served by telephone carriers receiving substantial high-cost subsidies per access line and in communities served by a carrier, Iowa Telecommunications Services, Inc., which receives very little subsidy per access line. ${ }^{32}$ I also show the amount of the high-cost subsidy paid through the federal program per month. At the bottom of this table, I show the rates paid for (unsubsidized) telephone and cable service in five of the eight largest Iowa cities, Cedar Rapids, Des Moines, Dubuque, Iowa City, Sioux City, and Waterloo, all served by Qwest which receives virtually no high-cost subsidies per line. ${ }^{33}$ Finally, Table 5 shows the average urban U.S. local residential telephone rate, as reported by the FCC, and the average national cable rate for enhanced basic cable services, as reported by NCTA.

\begin{tabular}{|l|l|l|l|l|l|}
\hline Communities & $\begin{array}{l}\text { Weighted average } \\
\text { population } \\
\text { density } \\
\text { (population/ } \\
\text { square mile) }\end{array}$ & $\begin{array}{l}\text { Weighted } \\
\text { average local } \\
\text { residential } \\
\text { telephone rate }\end{array}$ & $\begin{array}{l}\text { Federal } \\
\text { high cost } \\
\text { subsidy } \\
\text { per line }\end{array}$ & $\begin{array}{l}\text { Residential } \\
\text { telephone rate } \\
\text { plus federal } \\
\text { high-cost } \\
\text { subsidy }\end{array}$ & $\begin{array}{l}\text { Weighted } \\
\text { average cable } \\
\text { television rate }\end{array}$ \\
\hline $\begin{array}{l}\text { Rural communities } \\
\text { with federal high- } \\
\text { cost subsidies }\end{array}$ & 50 & 21.22 & 19.40 & 40.62 & 34.41 \\
\hline $\begin{array}{l}\text { Rural communities } \\
\text { with limited high- } \\
\text { cost subsidies }\end{array}$ & 35 & 25.91 & 1.63 & 27.54 & 53.55 \\
\hline $\begin{array}{l}\text { Six large urban } \\
\text { areas }\end{array}$ & 349 & 25.10 & 0.04 & 25.14 & 53.46 \\
\hline $\begin{array}{l}\text { U.S. average urban } \\
\text { rate }\end{array}$ & -- & 24.80 & -- & -- & 42.76 \\
\hline
\end{tabular}

Table 5: Residential telephone and cable television rates, sample of Iowa communities (\$/month)

Source: FCC, NCTA, telephone and cable companies, author's calculations

There are several surprises in Table 5. First, the subsidized rural companies' residential rates are much lower than urban rates in Iowa and lower than the average U.S. urban residential rate. The average subsidized rural rate, including various subscriber line charges and taxes is $\$ 21.22$ for the communities in the sample. The weighted average of rural residential rates for the Iowa rural carriers that are members of the Iowa Telecommunications Association is $\$ 11.46$ before subscriber line charges and taxes, which

\footnotetext{
32 The final sample included 18 of approximately 140 rural entities that receive subsidies and that serve towns for which there is a cable television service available. Residential rates were obtained by contacting the carriers or accessing their websites. These companies have 38,000 of the approximately 480,000 rural lines. The largely unsubsidized service is provided by Iowa Telecom, which has 250,000 rural lines in Iowa. As described above, it receives only Interstate Access Support which averages \$1.63 per line, a subsidy that is far below those received by the carriers in my "subsidized" sample. My "limited subsidy" sample includes 34 towns served by Iowa Telecom with a total population of 32,000. I should also note that I am only examining Iowa Telecom's service territory acquired from GTE and am not including Iowa Telecom's CLEC and subsequently-acquired operations.

${ }^{33}$ Qwest receives $\$ 0.04$ per month per line in high-cost subsidies.
} 
average $\$ 7.71$ in my smaller sample. ${ }^{34}$ This suggests that the average subsidized rural residential rate, including all charges, is slightly more than \$19 per month for all subsidized carriers, or even lower than the weighted average in the sample of urban communities in Table 5.

The second surprise is that cable rates in the sample of rural subsidized carriers are much lower than in the urban areas and even lower than the average U.S. rate. Given that cable television is not eligible for subsidies, it is remarkable that rates in rural areas could be so low. ${ }^{35}$ This result is not due to the fact that these cable services have few channels. In fact, the average number of channels in this sample is 60. However, it is quite likely that cable is not wired out over the entire franchise area in some of these rural areas. Moreover, the very large subsidies for the fixed costs of the infrastructure used for telephone service may well reduce the cost of delivering another service over the same facilities. Nonetheless, the low cable rates available in these rural areas suggest that subsidies are not necessary to provide affordable cable service to at least part of the franchise areas of the rural carriers. It may also suggest that allowing telephone companies to exploit these joint economies of cable plus telephony would be sufficient to keep rates low. Perhaps, "highcost" subsidies are not even necessary to keep cable/telephony rates reasonably close to those in the urban areas.

Third, even though the counties served by the largely unsubsidized rural carrier in my sample, Iowa Telecommunications, are less densely populated than those that are in the subsidized sample, ${ }^{36}$ the total charges for residential service plus the high-cost subsidies in the latter group are \$13 per month higher than the comparable measure for Iowa Telecom. Further investigation would be required to determine if this large difference reflects less efficient operations in the subsidized sector or "gold plating" of the subsidized companies' operations.

Finally, the difference between the Iowa Telecom rural rates, which reflected very limited subsidies, and urban telephone rates in Iowa is only $\$ 2.40$ per month. Thus, it is possible that elimination of the rural subsidies might be possible with only limited increases in local rural rates. However, it is likely that Iowa Telecom's local service is not comparable to the urban Iowa services in Table 5, because the latter cover a larger calling area and may offer superior service. But even adding Extended Area Service (EAS) charges to the Iowa Telecom charges in Table 5 would only raise the average total rate plus subsidy to about $\$ 31$ per month. ${ }^{37}$ Unfortunately, I cannot quantify the potential differences in service quality between Qwest's large-city services and those of Iowa Telecom. The difference between Qwest's urban rates and Iowa Telecom's total rural rates (adding the EAS charges and its limited subsidies) for their current services is only about $\$ 2$ per month. This pales in comparison with the average high-cost subsidy of \$19.40 per

\footnotetext{
${ }^{34}$ These data were obtained from the Iowa Utilities Board. The data set did not contain the additional charges, including subscriber line charges and taxes, charged by each carrier. These were obtained from the carriers themselves.

35 Timothy Tardiff has suggested to me that because the cable television service is sometimes offered over some of the facilities used to deliver subsidized telephone service, the effect of the subsidy program may be to lower cable television rates as well.

${ }^{36}$ The population densities reported in Table 5 are for the primary towns or cities served by the systems. They may not reflect the actual densities of the entire franchise areas served by the carriers.

37 The EAS charges vary widely. In my sample, they average only \$2 per month, but I have used \$3.50 per month in this calculation.
} 
month paid to the other rural Iowa companies in my sample and the average subsidy across all small rural carriers in Iowa of almost \$23 per month.

What does this analysis of Iowa tell us about the high-cost rural subsidy program? If the high-cost subsidies were abolished, the affected rural carriers in Table 5 might have to raise rates by $\$ 19.40$ per month to offset the loss of subsidy monies, assuming no change in the efficiency of their operations. But even with this increase in rates, their rural customers' telephone plus cable rates would still be lower than those facing Iowa Telecom's customers or Qwest's urban customers. At the very least, it would seem reasonable to allow the subsidized telephone rates to rise to the average urban rate, or to $\$ 24.80$ per month. $^{38}$

\subsection{Urban versus rural telephone penetration}

The goal of the high-cost universal service program, as well as the income-based subsidies in the form of Lifeline or Link-Up payments, is to assure that rural households have access to telephone service at rates comparable to those who live in urban areas. I have already shown that for Iowa at least, the program is working too well. Rural households appear to have even lower telephone rates than those living in urban areas and even lower cable television rates. But have the various subsidy programs achieved rates of telephone penetration in rural areas that are equal to those achieved in urban areas?

There are no data on telephone penetration in rural areas, per se. The Census Bureau's March Current Population Survey asks households if they have telephone service of any kind, wireline or wireless. The most recent comprehensive data on telephone penetration by state by income level find that 94.6 percent of U.S. households had telephone service in March 2007. To obtain at least a rough idea if rural areas have telephone penetration that is equal to that in urban areas, I reproduce the March 2007 data for the most rural states in the country, including Iowa in Table 6. Because telephone subscription demand is influenced substantially by income, I show the penetration data for the entire state sample and for households with low to modest family income.

These data demonstrate that telephone penetration, when standardized by income class, is generally no lower in rural states than for the entire country. Without adjusting for income, six of the thirteen most rural states have telephone penetration that is below the U.S. average, but the differences are not statistically significant. ${ }^{39}$ However, in the three low to middle income ranges shown, the rural states are generally above the national average - 26 of the 39 observations are greater than the U.S. average - but once again given the small sample sizes, these differences are not statistically significant.

Unfortunately, there are no studies of the demand for telephone service in rural areas in part because data on telephone rates are not generally available for small rural carriers. Most studies of the effects of universal service policy focus on the FCC's Lifeline and

\footnotetext{
${ }^{38}$ It has been suggested by Thomas Hazlett that the subsidized rates are capitalized into land values in rural areas. At most, my results would suggest that rural households receive a \$186 subsidy per year. The present value of this subsidy at any reasonable consumer discount rate would be no more than $\$ 2,000$. It would very difficult to confirm the effects of such a small subsidy on rural land prices. Surely, this effect would pale in comparison to the effect of traditional agricultural subsidies and, in particular, the current subsidy on cornbased ethanol.

${ }^{39}$ The Census Bureau publishes estimated standard errors which the FCC converts into confidence levels by individual state. There are no published confidence levels by state by income level. The differences between the average state values across all income categories and the U.S. average penetration are never as great as the $95 \%$ confidence level published by the FCC.
} 
Link-Up policies, which provide subsidies to carriers who offer new or continuing service to low-income households. ${ }^{40}$ It would be very helpful if the FCC were to obtain the requisite data and commission a study of the determinants of household demand for telephone connectivity in rural areas. The older studies of residential demand have found that the price elasticity of demand is extremely low.

\begin{tabular}{|l|l|l|l|l|l|}
\hline & & \multicolumn{3}{|c|}{ Percentage of Households with Telephone Service } \\
\hline State & $\begin{array}{l}\text { Percent } \\
\text { rural }\end{array}$ & All households & $\begin{array}{l}\text { Household } \\
\text { income: } \\
\mathbf{\$ 3 0 - 3 9 , 9 9 9}\end{array}$ & $\begin{array}{l}\text { Household } \\
\text { income: } \\
\mathbf{\$ 2 0 - 2 9 , 9 9 9}\end{array}$ & $\begin{array}{l}\text { Household } \\
\text { Income: } \\
\mathbf{\$ 1 0 - 1 9 , 9 9 9}\end{array}$ \\
\hline Vermont & 61.8 & 97.5 & 99.3 & 98.4 & 95.2 \\
\hline Maine & 59.8 & 97.1 & 97.6 & 99.4 & 97.7 \\
\hline West Virginia & 53.9 & 93.4 & 95.0 & 97.7 & 96.0 \\
\hline Mississippi & 51.2 & 90.7 & 96.7 & 93.9 & 92.9 \\
\hline South Dakota & 48.1 & 97.5 & 99.6 & 97.5 & 97.2 \\
\hline Arkansas & 47.5 & 90.6 & 95.8 & 94.1 & 92.6 \\
\hline Montana & 45.9 & 95.7 & 98.2 & 97.3 & 95.6 \\
\hline Alabama & 44.6 & 91.2 & 90.9 & 93.1 & 92.5 \\
\hline Kentucky & 44.2 & 94.2 & 96.3 & 95.5 & 95.2 \\
\hline North Dakota & 44.1 & 97.7 & 100 & 98.5 & 97.5 \\
\hline $\begin{array}{l}\text { New } \\
\text { Hampshire }\end{array}$ & 40.7 & 96.7 & 97.8 & 96.2 & 94.4 \\
\hline $\begin{array}{l}\text { North } \\
\text { Carolina }\end{array}$ & 39.8 & 93.4 & 97.7 & 95.0 & 90.5 \\
\hline Iowa & 38.9 & 96.3 & 98.9 & 97.4 & 97.8 \\
\hline U.S. Average & 21.0 & 94.6 & 96.8 & 95.9 & 94.1 \\
\hline
\end{tabular}

Table 6: March 2007 telephone penetration in the most rural states

Source: U.S. Bureau of the Census, Current Population Survey; FCC at http://hraunfoss.fcc.gov/edocs_public/attachmatch/DOC-280982A1.pdf.

Nor is wireless service ${ }^{41}$ (cellular) less available in rural areas than in urban areas. The FCC reports that 99.3 percent of the population in rural counties in the U.S. is served by at least one wireless carrier. ${ }^{42}$ Moreover, citing a CTIA study, the FCC points out that wireless penetration in 2005 was only slightly lower in rural areas than in urban areas, 68 percent in rural areas compared with 75 percent in urban areas. ${ }^{43}$ Given the generally lower level of household income in rural areas, this difference could simply be a reflection of

\footnotetext{
${ }^{40}$ See the work of Christopher Garbacz and Leonard Thompson (2008) and Ackerberg, Riordan, Rosston and Wimmer (2008). Rosston, Savage and Wimmer (2006) have found that high-cost universal service support for the rural operations of the large Bell companies has no effect on rural residential rates but is associated with lower urban business rates.

${ }^{41}$ Since 1999, wireless carriers have been eligible to receive high-cost subsidies if they are certified as "competitive eligible telecommunications carrier" (CETC) that competes with the local incumbent to serve as a subscriber's primary carrier. These CETCs, which include wireless and fixed-wire competitors of the rural ILECs now receive slightly more than one-fourth of all federal high-cost support funds.

${ }^{42}$ See FCC, $12^{\text {th }}$ Annual CMRS Competition Report (Annual Report and Analysis of Competitive Market Conditions with Respect to Commercial Mobile Services), February 4, 2008, S103-110. ${ }^{43}$ Id.
} 
differences in purchasing power. Despite the differences in population density, fully 70 percent of rural wireless carriers offer pricing plans that are comparable to those available in the national plans of the major wireless carriers. ${ }^{44}$ Given these facts, one must at least suggest that the high-cost subsidy program for rural telephony may no longer be necessary.

\subsection{The cost of the high-cost program}

Because the subsidy monies for the FCC's universal service program are obtained from a tax on interstate and international revenues, the cost of the universal service program is substantial. The high-cost program is primarily a redistribution of income from all persons using interstate and international services to small carriers and their customers in rural areas that comprise about 20 percent of the country. But the major cost is the lost output in interstate/international calling caused by a tax of 9 to 10 percent of calling revenues. Hausman has shown that, given the estimated price elasticity of demand for these services and the substantial gap between the price and the marginal cost of a call, the cost of raising the universal-service funds is 1.25 times the revenue raised. ${ }^{45}$ Thus, the $\$ 4$ billion highcost program costs the economy another $\$ 5$ billion each year in lost output.

\subsection{Reform?}

There are at least two directions for reform of this high-cost subsidy program. First, its magnitude should be reduced substantially. I have provided some evidence that both cable rates and wireless rates are not noticeably higher in rural areas than in urban areas. Would rural telephone rates increase if the high-cost subsidy program were cut back significantly? My analysis suggests that rural rates in Iowa are now substantially lower than urban rates because of an average subsidy of nearly $\$ 23$ per month. Reducing the subsidy by $\$ 4$ per month and perhaps by more would allow the current small, dispersed rural companies to still offer service to their residential customers at rates paid by their big-city relatives. A sharp reduction in subsidies might lead to a substantial consolidation of the thousands of small rural carriers that survive on these subsidies and a major improvement in operating efficiency. Even if high-cost subsidies are eliminated altogether, my analysis shows that the package of local telephone service and cable television service in a sample of Iowa rural areas would likely remain below the price of a local telephone/cable services in urban areas of that state.

Second, the FCC could at least move away from the tax on interstate and international revenues towards a more efficient support mechanism. The most obvious of these would be a simple "numbers" tax, one which charged each subscriber a flat fee for each telephone number it holds. ${ }^{46}$ Since the demand to have telephone service at all is much less price sensitive than the demand for interstate/international calling, this change would greatly reduce the social cost of the program.

The Federal-State Joint Board on Universal Service, which develops policy recommendations for the various universal service programs, has struggled with both the size of the high-cost program and its inefficient funding mechanism, but has acted very slowly to suggest reform of the program for obvious reasons. There are more than 1,000 small, rural carriers scattered across the country with more than 20 million of the country's

\footnotetext{
${ }^{44} \mathrm{Id}$.

45 Hausman (1998).

${ }^{46}$ See The Progress and Freedom Foundation (2005) for a discussion of such a funding mechanism.
} 
163 million access lines. These carriers and their customers constitute a powerful lobby against any reduction in the program, and their political influence is reflected in the Congress, particularly in the Senate. Recently, the Joint Board recommended placing a cap on the high-cost universal service fund, and the FCC has now done so. ${ }^{47}$ Unfortunately, in this recommended decision, the Joint Board also recommended extending the program to the subsidization of new broadband services, but it provided no analysis of the need for such a program or even of the need to continue the program for traditional telephone services.

Attempts to change the tax mechanism for supporting the universal service program appear to have stalled. At present, it is likely that very few telephone customers understand the large array of taxes and universal-service charges that are included on the last page of their telephone bills. Substituting a numbers tax for all of these very inefficient taxes would greatly reduce the economic inefficiency of the program and simplify the customers' bills, but it also might make the program much more transparent to consumers. ${ }^{48}$ Clearly, such a change creates some risk to the political viability of the program.

The high-cost universal service program is surely an example of the continuation of a very complex regulatory program designed to keep rates low for a favored political group despite the fact that it may no longer be necessary. It is not, however, an example of the regulatory kleptocracy that Kahn describes. The regulators are not extracting the costs of the program from the sunk costs of the incumbent carriers. Rather, they are maintaining and expanding a very inefficient program of cross subsidies which penalize heavy users of interstate and international services. It is likely that this policy survives despite any proven need for it because few of these latter users have even a vague idea of their contribution to these costs which are displayed in an incomprehensible fashion on the pages and pages of monthly bills that they receive from the carriers.

\section{$5 \quad$ Regulating cable television rates, 1993-96}

The history of U.S. policy towards cable television is a classic tale of government creation, protection, and subsequent regulation of monopoly. Aided and abetted by strong Congressional pressure, the Federal Communications Commission had allocated the television broadcast spectrum in a manner designed to vest large monopoly profits in the licensees. In the 1950s, by geographically dispersing allocations in a band with limited capacity, the VHF band, the FCC created concentrated local television markets throughout the country, thereby limiting the number of national networks to three. It then spent two decades ruminating about television network market power.

\subsection{The early years of cable television policy}

When cable television emerged in the late 1950s and early 1960s, it was seen simply as a technology to improve local signal quality in areas where local topography interrupted

\footnotetext{
${ }^{47}$ FCC, Order, In the Matter of High-Cost Universal Service Support, Federal-State Board on Universal Service, WC Docket 05-337, CC Docket 96-45, May 1, 2008.

${ }^{48} \mathrm{I}$ am reminded by the editors of this volume that Professor Kahn was an advocate of such transparency when he was Chairman of the New York Public Service Commission and later when he was Chairman of the Civil Aeronautics Board. See Mc Craw (1984), pp. 245-54; 270-72.
} 
local broadcast signals. It was soon clear, however, that cable could bring in distant signals and even originate its own programming, clear threats to local broadcasters. As a result, the FCC was forced by political pressures to begin to regulate cable television, limiting its ability to import distant signals, banning “pay television” broadcasts of most live sporting events and older motion pictures, and imposing a variety of other non-remunerative local programming obligations between 1966 and 1972. This protected the monopoly rents of broadcasters for the remainder of the 1970 s. $^{49}$

The federal courts overturned several of the FCC's anti-competitive cable rules, including the pay-television restrictions and the local origination requirements in the late 1970s. ${ }^{50}$ At the same time, the FCC began to feel the political pressure from the deregulatory movement that had gripped the country in the mid 1970s and eventually led to substantial deregulation of stock-market commissions, consumer interest rates, oil prices, airlines, railroads, and trucking. As a result, the Commission began to reverse course and eliminate some of its more onerous restrictions on cable television systems, eventually eliminating all of the signal-carriage restrictions in 1979. Subsequently, the Congress passed the 1984 Cable Communications Policy Act which eliminated all regulation of retail cable, thereby ending several decades of state-local monopoly franchising and regulation of cable television.

\subsection{From regulation to deregulation to re-regulation}

The deregulation of cable television was an enormous success, inducing cable television systems to expand channel capacity and thereby inducing a substantial increase in the number of cable networks distributed to the cable systems over geostationary satellite links. However, these new programming services came at an increase in price to subscribers. The increase in price was clearly less than the increase in value to most subscribers, as Harold Furchtgott-Roth and I demonstrated in an econometric study of subscriber demand. ${ }^{51}$ We concluded that the increases in services available to subscribers in 1992 compared with those available in 1983-84 were worth $\$ 6.5$ billion more than the increases in the price paid for such services. ${ }^{52}$ Further evidence may be found in the increasing number of subscribers despite the rising prices (See Table 7).

Cable rates rose at an inflation adjusted rate of 5.76 percent per year between 1986, the year deregulation became effective, and 1992, while cable subscribers grew at an annual average rate of 5.9 percent. This growth in subscriptions reflected the increasing value of cable television service to subscribers as cable systems added new channels and charged somewhat more for the service.

\begin{tabular}{|l|l|l|}
\hline Year & $\begin{array}{l}\text { Real price - } \\
\text { expanded basic service } \\
\mathbf{( 1 9 8 2 - 8 4} \text { \$/month) }\end{array}$ & $\begin{array}{l}\text { Total cable } \\
\text { subscribers } \\
\text { (millions) }\end{array}$ \\
\hline $\mathbf{1 9 8 6}$ & 9.74 & 38.2 \\
\hline $\mathbf{1 9 8 7}$ & 10.72 & 41.2 \\
\hline $\mathbf{1 9 8 8}$ & 11.72 & 44.2 \\
\hline
\end{tabular}

\footnotetext{
${ }^{49}$ For the early history of cable television regulation, see Crandall and Besen (1981) and Crandall and Furchtgott-Roth (1996).

${ }^{50}$ Home Box Office v. FCC, 567 F.2d 9 (1977), cert. denied, 434 U.S. 829 (1977).

${ }^{51}$ Crandall and Furchtgott-Roth (1996), Ch. 3.

${ }^{52}$ Id., p. 58.
} 


\begin{tabular}{|l|l|l|}
\hline $\mathbf{1 9 8 9}$ & 12.27 & 47.5 \\
\hline $\mathbf{1 9 9 0}$ & 12.84 & 50.5 \\
\hline $\mathbf{1 9 9 1}$ & 13.29 & 52.6 \\
\hline $\mathbf{1 9 9 2}$ & 13.60 & 54.3 \\
\hline $\mathbf{1 9 9 3}$ & 13.42 & 56.2 \\
\hline $\mathbf{1 9 9 4}$ & 14.59 & 59.5 \\
\hline $\mathbf{1 9 9 5}$ & 15.14 & 61.6 \\
\hline $\mathbf{1 9 9 6}$ & 15.56 & 63.0 \\
\hline $\mathbf{1 9 9 7}$ & 16.50 & 64.2 \\
\hline $\mathbf{1 9 9 8}$ & 17.06 & 65.1 \\
\hline $\mathbf{1 9 9 9}$ & 17.36 & 65.9 \\
\hline $\mathbf{2 0 0 0}$ & 17.47 & 66.6 \\
\hline $\mathbf{2 0 0 1}$ & 17.83 & 66.9 \\
\hline $\mathbf{2 0 0 2}$ & 19.19 & 66.1 \\
\hline $\mathbf{2 0 0 3}$ & 19.89 & 66.0 \\
\hline $\mathbf{2 0 0 4}$ & 20.24 & 65.4 \\
\hline $\mathbf{2 0 0 5}$ & 20.46 & 65.4 \\
\hline $\mathbf{2 0 0 6}$ & 20.42 & 65.6 \\
\hline
\end{tabular}

Table 7: Cable Subscribers and Real Cable Rates, 1986-2006

Source: NCTA

Despite the obvious fact that more consumers were enrolling in cable television subscriptions despite the rate increases, Congress responded to a perceived popular outcry against the cable "monopolists" by passing the 1992 Cable Act, which instituted federal rate regulation of cable television for the first time. The first regulations under this Act were issued in April 1993, and they created controversy from the outset. Cable rates were to be based on a "benchmark" competitive rate determined by the FCC's staff regression analysis of rates across the country. At first, this analysis suggested a 10 percent reduction in rates, but the Commission later amended its results and called for a 17 percent reduction. ${ }^{53}$ In addition, the Commission allowed cable systems to charge very little for any new channels they added to their lineups.

As Figure 2 shows, the number of national cable programming services (networks) grew very slowly between 1993 and 1995, reflecting the stringent price controls on new networks. These effects were mirrored in and probably driven by the downturn in cable rates in 1993. Moreover, cable television program costs as a share of total revenues fell in 1992, a further reflection of the reluctance of cable systems to invest in new programming under the new regulatory regime. ${ }^{54}$

\footnotetext{
${ }^{53}$ Id., pp.39-41.

${ }^{54}$ U.S. Bureau of the Census, Annual Survey of Service Industries. See also Hazlett and Spitzer (1997), Figure 5-8.
} 


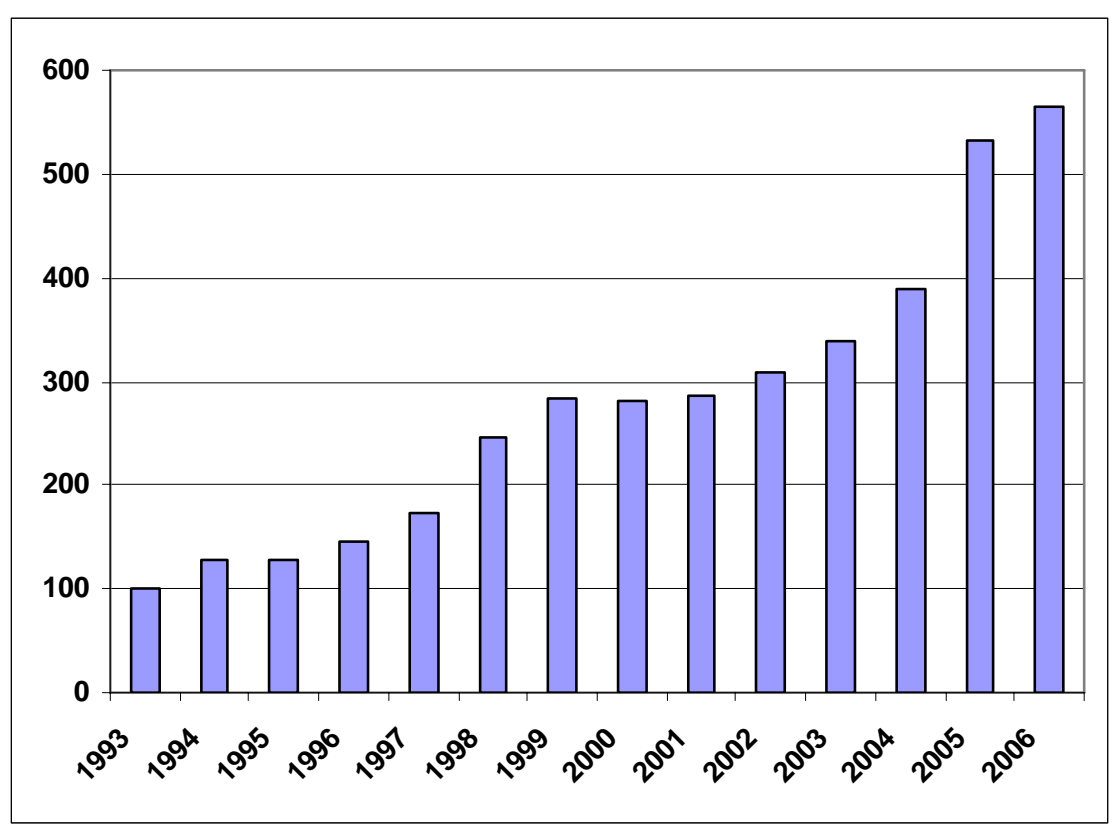

Figure 2: Growth of national cable networks, 1993-2006

Source: NCTA from FCC data

After growing at an annualized rate of 5.5 percent since 1986, real cable rates were driven down by the FCC's new rules by 1.3 percent in 1993 according to the NCTA data shown in Table 7. Though less severe than the FCC had originally suggested, this decline in rates was clearly a shock to the market as shown by the effect on the country's largest cable company's share price. Figure 3 shows that Comcast's share price fell dramatically in late 1993 and early 1994, undoubtedly in response to the new FCC rules, and it remained depressed into early 1997 - throughout a period of generally rising stock prices.

\subsection{Surrender by the FCC}

Surprisingly, the FCC's regulation of the cable industry proved to be short lived. The 1992 law was largely repealed as part of the 1996 Telecommunications Act, but the FCC threw in the towel far earlier than 1996. As Hazlett and Spitzer recount it, the Commission decided that its attempt to regulate rates was simply unmanageable. Because cable operators could adjust their offerings in many dimensions, particularly by reducing quality in response to binding rate regulation or by shifting to unregulated "a la carte" channels, the Commission quickly became frustrated. In November 1994, the FCC loosened its grip on rates by allowing cable operators to charge higher rates on new program channels added to their packages. Then, in April 1995, the FCC began to negotiate "social contracts" with the large cable companies, allowing them to avoid rate regulation on upper programming tiers if they retained a limited-channel basic offering at low rates and agreed to invest in network upgrades. ${ }^{55}$

\footnotetext{
${ }^{55}$ Hazlett and Spitzer (1997), pp.212-15.
} 


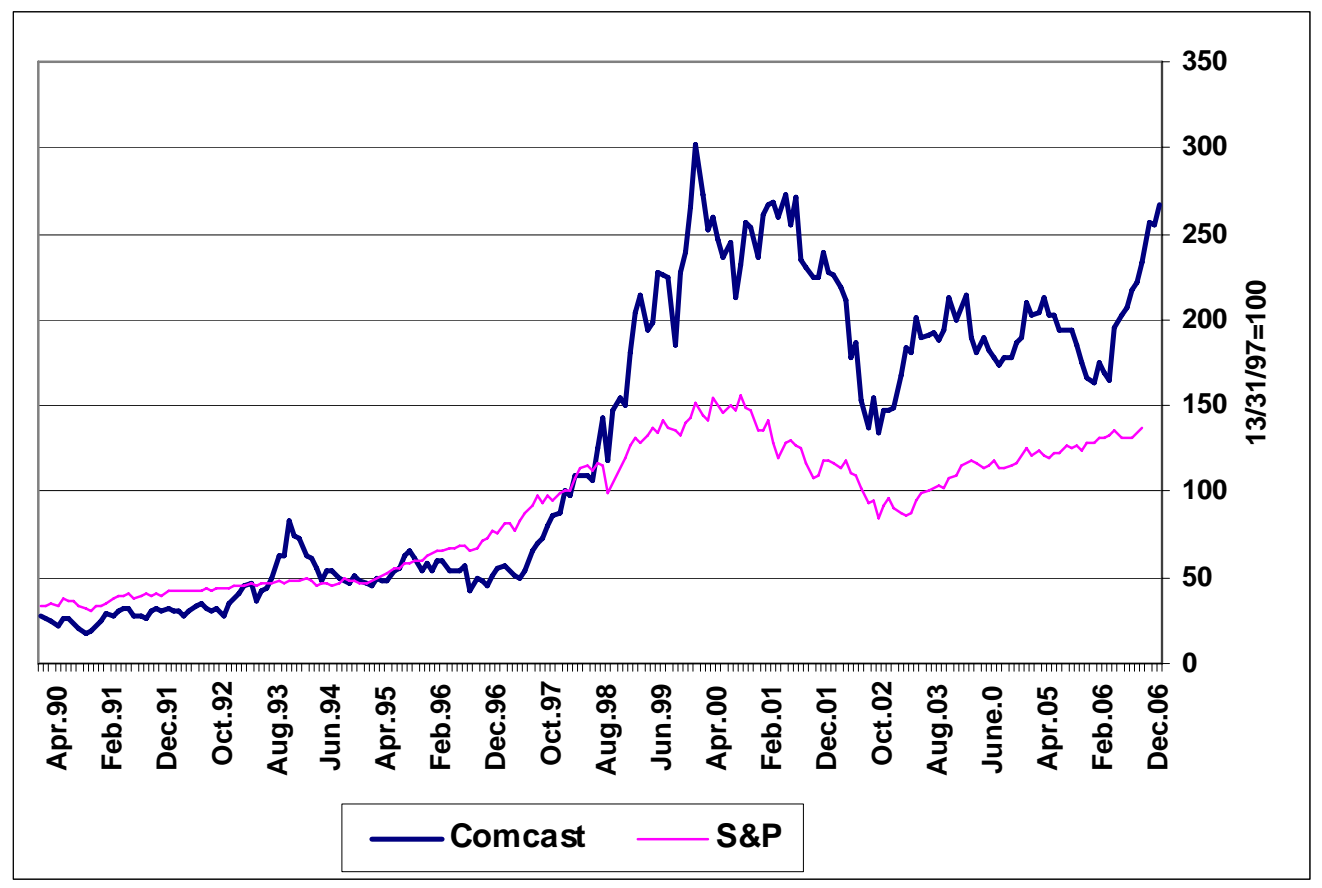

Figure 3: Comcast stock price v. S\&P 500

Source: finance.yahoo.com

Hazlett and Spitzer argue that the shift to Republican control of the Congress in 1994 had convinced the FCC that its regulations could not be sustained. As a result, it quickly shifted gears, allowing real cable rates to rise once again at their pre-regulation rate of growth. As Table 7 shows, real cable rates rose at an annual rate of more than 6 percent per year in 1994 and 1995. By 1995, real cable revenues were rising by nearly 7 percent per year once again. The entire unfortunate experiment in rate regulation of a highlydifferentiated, non-essential consumer service had come largely to an end. The 1996 Telecommunications Act formalized the FCC's surrender.

Nevertheless, cable stock prices did not begin to rise again until 1997, after the Congress confirmed the FCC's implicit decision to deregulate cable rates two years earlier. After that, Comcast's value increased nearly six-fold and then declined by half as the technology bubble burst in 2000.

This entire experience in rate regulation of an industry which still had considerable market power - the cable industry did not experience serious competition from highpowered satellite services until after 1994 - demonstrates the futility of regulation of a highly differentiated service. Regulators cannot control both the prices and the quality of essentially an information-entertainment service. Therefore, attempts to control rates lowered quality, reduced consumer welfare, lowered the value of the regulated enterprises, and reduced the growth of cable programming expenditures, thereby harming even the Hollywood studios. Given that virtually everybody lost from this exercise, allowing the cable companies to raise rates once again and restore the imperfectly-competitive market equilibrium was a pure Pareto improvement. More importantly, there was no large lobbying interest attempting to perpetuate this futile regulatory program. 
The competition from satellite services began when DirecTV launched its first satellite in 1994. EchoStar followed with its DISH satellite service in 1995. Thereafter, as Table 7 demonstrates, cable subscriber growth ground to a halt. Between 1996 and 2006, cable operators added fewer than 3 million subscribers, and their real rate of rate increases for expanded basic service declined to less than 3 percent per year despite continued increases in channels offered. Had the Congress simply waited two more years, the pressure for cable rate regulation probably would have abated. Had the FCC recognized that satellite competition was just around the corner, it might have pursued a less aggressive course in 1993, thereby avoiding the unfortunate feedback effects on cable network investment. But with the cable companies enjoying a market value far in excess of the reproduction cost of their assets, the temptation for kleptocracy was simply too great. ${ }^{56}$

\section{Conclusions}

I have reviewed three FCC regulatory programs, two of which are still in place, and one of which has been discarded. Each reflects complex micro-management of the regulatory process in an era of increasing competition and a general trend towards deregulation. Two of the three programs are clearly examples of the regulatory kleptocracy that Professor Kahn has so cogently described in two monographs.

The first of these policies, attempting to stimulate local telephone competition through network unbundling was clearly a failure yet the FCC tenaciously clung to it until the U.S. Court of Appeals forced the Commission to relent and reduce its scope. Its costs far exceeded any benefits that it might have created. The program still exists, but it has been scaled back substantially because of the court reversals. Had the courts not reversed the FCC's last gasp at perpetuating the UNE-P, it is possible that the FCC would still be adjusting the UNE-P in a desperate attempt to breathe life into what remained of (the former) AT\&T and MCI at a substantial cost to the incumbent local telephone companies.

The second, high-cost universal service subsidies for rural telephone companies, is extremely expensive, costing long-distance rate payers $\$ 4$ billion and reducing social output by another $\$ 5$ billion. Despite these costs, there is no empirical evidence that the program has any effect on rural telephone subscriptions or that there is truly a need for the service. Rural cable television and wireless (cellular) telephone rates appear to be affordable, and cable telephony and other VoIP services receive no such subsidies although the subsidies to rural telephone companies may contribute to their ability to offer cable television at slightly lower rates. Moreover, I have provided some evidence that the program allows rural subscribers to pay even less than urban subscribers for traditional telephone service. Over the years, this program has become increasingly complicated, and it must now be overhauled substantially because of the declining revenue base from which the subsidy monies are extracted. With so many competitive options available to subscribers today, in both rural and urban areas, the program may no longer be necessary. Unfortunately, this is a possibility that the FCC is unlikely even to investigate because the consumers from whom the cost of the program is extracted are likely unaware of this burden.

\footnotetext{
${ }^{56}$ The Tobin's q ratio for cable television was estimated by Hazlett and Spitzer (1997), p.23, to be 3.56 in 1993, or roughly four times the average for the average of companies listed on the New York Stock Exchange.
} 
The third program, regulating cable television rates provided no benefits that I can identify but substantial costs in the form of reduced programming quality. Had the FCC not abandoned it within three years of its implementation, this regulatory policy likely would have collapsed because it was simply unenforceable. Even a regulatory kleptocracy would not likely continue to extract the costs of such a program from the incumbent cable companies if it generated negative benefits to the target constituency.

In Professor Kahn's parlance, the FCC could not and, in the case of high-cost universal service subsidies still cannot, "let go" of the first two policies because they convey or conveyed benefits to powerful political interests even if these benefits are less than the social costs of the policies. AT\&T and MCI and the new local carriers still in operation were able to persuade the FCC through 2003 to continue a futile network unbundling policy when the failure of this policy was quite clear. The high-cost subsidies remain in place because hundreds of small rural carriers have persuaded politically-sensitive regulators and legislators, without having to proffer serious empirical evidence, that these subsidies are necessary to keep rural telephony affordable and alive. Efforts to modify or reduce the cost of this policy have languished, undoubtedly because few Americans recognize how much this policy costs them and no one knows if it is even necessary.

\section{$7 \quad$ References}

Ackerberg, D.A., M.H. Riordan, G.L. Rosston and B.S. Wimmer (2008) Low-Income Demand for Local Telephone Service: The Effects of Lifeline and Linkup. Stanford Institute for Economic Policy Research: Stanford University.

Crandall, R. (2005) Competition and Chaos: U.S. Telecommunications Since the 1996 Telecom Act. The Brookings Institution: Washington.

Crandall, R. and L. Waverman (2006) "The Failure of Competitive Entry into Fixed-Line Telecommunications: Who Is at Fault?” Journal of Competition Law and Economics, 2: 113-148.

Crandall, R. and S. Besen (1981) "The Deregulation of Cable Television," Law and Contemporary Problems, Duke University School of Law, 44: 77-124.

Crandall, R. and H. Furchtgott-Roth (1996) Cable Television: Regulation or Competition? Washington: The Brookings Institution.

Crandall, R. and L. Waverman (2000) Who Pays for Universal Service? When Telephone Subsidies Become Transparent. Washington: The Brookings Institution.

Economides, N., K. Sim, and V. Viard (2008) "Quantifying the Benefits of Entry into Local Phone Service,” NET Institute, Working Paper 08-01.

Faulhaber, G. (1975) "Cross-Subsidization: Pricing in Public Enterprises," American Economic Review, 65: 966-77. 
Garbacz, C. and H. Thompson, Jr. (2008) "Lifeline Subsidy Programs and Telephone Penetration Demand: Adjusting for Endogeneity,” Working Paper.

Garbacz, C. and H. Thompson, Jr. (1997) "Assessing the Impact of FCC Lifeline and Linkup Programs on Telephone Penetration,” Journal of Regulatory Economics 11:67-78.

Hausman, J. (1998) “Taxation by Telecommunications Regulation,” Tax Policy and the Economy, 12: 29-48.

Hazlett, T. and M. Spitzer (1997) Public Policy towards Cable Television: The Economics of Rate Controls. MIT Press and AEI Press: Cambridge, MA.

Kahn, A. (1998) Letting Go: Deregulating the Process of Deregulation. Institute of Public Utilities and Network Industries, Michigan State University.

Kahn, A. (2001) Lessons from Deregulation: Telecommunications and Airlines After the Crunch. AEI-Broookings Joint Center for Regulatory Studies: Washington.

McCraw, T. (1984) Prophets of Regulation. Harvard University Press: Cambridge, MA.

Progress and Freedom Foundation (2005) The Digital Age Communications Act. Report of the Universal Service Working Group, December.

Rosston, G., S. Savage, and B. Wimmer (2006) The Impact of 'Deregulation' on Regulator Behavior: An Empirical Analysis of the Telecommunications Act of 1996. Stanford Institute for Economic Policy Research: Stanford University.

Tardiff, T. and D. Weisman (2008) “The 'Dominant Firm' Revisited: The Case of Telecommunications,” paper delivered at the International Telecommunications Society, $17^{\text {th }}$ Biennial Conference, Montreal, Canada.

U.S. Federal Communications Commission (1996) Implementation of the Local Competition Provisions of the Telecommunications Act of 1996, First Report and Order, CC Docket No. 96-98.

U.S. Federal Communications Commission (1999) Implementation of the Local Competition Provisions of the Telecommunications Act of 1996, Third Report and Order and Fourth Further Notice of Proposed Rulemaking, CC Docket No. 96-98. 